\title{
OPTIMASI SISTEM PENGANGKUTAN SAMPAH KECAMATAN JATI, KABUPATEN KUDUS, JAWA TENGAH
}

\author{
Bimastyaji Surya Ramadan ${ }^{1, *}$, Rahayu Puji Safitri', Mohammad Rafif Dwi \\ Cahyo $^{1}$, Yudha Gusti Wibowo ${ }^{2}$
}

$\left.{ }^{1}\right)$ Departemen Teknik Lingkungan, Fakultas Teknik, Universitas Diponegoro, Jl. Prof. Soedarto,
SH, Kampus Undip Tembalang, Semarang, Indonesia 50275

2) Program Studi Teknik Lingkungan, Fakultas Teknik, Universitas Jambi, Jl. Raya JambiMuara Bulian km. 15, Mandalo Indah, Muaro Jambi, Jambi, Indonesia 36122

e-mail: bimastyaji@live.undip.ac.id

\begin{abstract}
Abstrak
Pengangkutan sampah merupakan bagian dari kegiatan pengelolaan sampah yang berpengaruh pada biaya keseluruhan pengelolaan dimana anggaran pengangkutan sampah dapat mencapai $60 \%$ dari total seluruh biaya pengelolaan sampah. Tujuan dari penelitian ini adalah untuk mengoptimasi sistem manajemen pengangkutan sampah di Kecamatan Jati, Kabupaten Kudus yang dikelola oleh Dinas Perumahan, Kawasan Permukiman dan Lingkungan Hidup, Kabupaten Kudus. Optimasi dilakukan dengan membandingkan sistem manajemen pengangkutan sampah eksisting dengan merencanakan sistem baru yang dibuat dengan berpedoman pada Peraturan Menteri Pekerjaan Umum Nomor 3 Tahun 2013 tentang Penyelenggaraan Prasarana dan Sarana Persampahan dalam Penanganan Sampah Rumah Tangga dan Sampah Sejenis Sampah Rumah Tangga. Sistem informasi geografis digunakan untuk mendapatkan waktu trip dan jarak terdekat dari tempat pemrosesan akhir. Hasil penelitian menunjukkan bahwa terdapat 2 truk yang dapat dioptimasi jaraknya sehingga proses pengangkutan sampah lebih maksimal. Di samping itu, optimisasi rute yang dilakukan dapat mengurangi biaya pengangkutan secara keseluruhan. Hasil penelitian ini diharapkan dapat menurunkan dampak sosial akibat tidak terlayaninya beberapa wilayah oleh pengangkutan sampah serta mengurangi biaya dari kegiatan pengelolaan sampah.
\end{abstract}

Kata kunci: optimasi pengangkutan sampah; pola pengangkutan, rute pengangkutan

\begin{abstract}
Waste transportation is part of waste management activities that affect the overall budget of waste management where the waste transportation budget can reach $60 \%$ of the total budget of waste management. The purpose of this study was to optimize the waste transportation management system in Jati Subdistrict, Kudus Regency, which is managed by the Housing, Settlement and Environment Agency, Kudus Regional Government. Optimization was done by comparing the existing waste transportation management system with the new management system made by referring to the Minister of Public Works Regulation No. 3 of 2013 concerning the Implementation of Solid Waste Infrastructure and Facilities in Household Waste Handling and Household Waste. Geographical information system was used to get the efficient trip time and the closest distance from the landfill site. The results showed that there were 2 trucks that could be optimized so the process of transporting waste could be more efficient. In addition, route optimization can reduce overall transportation costs. The results of this study were expected to reduce the social impact of unserved area and reduce the overall costs of waste management activities.
\end{abstract}

Keywords: waste transportation optimization; transporting pattern, transporting route 


\section{Pendahuluan}

Menurut Undang-Undang Republik Indonesia Nomor 18 tahun 2008 tentang Pengelolaan Sampah, Penanganan sampah meliputi kegiatan pemilihan, pengumpulan, pengangkutan, pengolahan dan pemrosesan akhir sampah. Penanganan sampah yang baik ini dapat memastikan kesehatan masyarakat dan kualitas lingkungan terjaga (Zalukhu dan Mirwan, 2018). Sistem pengangkutan sampah yang optimal merupakan salah satu indikator penanganan sampah yang baik. Pengangkutan sampah merupakan kegiatan pemindahan sampah dari TPS / TPST / TPS3R atau tempat penampungan sampah menuju ke tempat pemrosesan akhir (TPA). (Pemerintah RI 18, 2008).

Pengangkutan sampah sangat dipengaruhi oleh laju pertumbuhan, baik dari sektor industri, ekonomi, pertanian maupun perdagangan (Ismail dkk., 2012). Pertumbuhan tersebut memacu kebutuhan armada yang berakibat pada peningkatan kebutuhan armada pengangkutan sampah. Ketersediaan armada ini juga berdampak pada persentase pelayanan pengelolaan sampah di suatu kota (Zalukhu dan Mirwan, 2018). Dalam kegiatan perencanaan pengangkutan sampah, pemilihan rute kendaraan dan jadwal pengangkutan sangat penting dalam menentukan jarak total perjalanan armada (Huang dan Lin, 2015). Sebuah rute / pola pengangkutan dapat dikategorikan optimal apabila mampu didesain sependek mungkin dan memiliki hambatan paling kecil dari titik TPS ke TPA (Ridha dkk., 2016). Optimasi dapat dilakukan dengan menggunakan sistem informasi geografis (Arnatha, 2012) maupun menggunakan model simulasi lainnya seperti sistem dinamik (Anagnostopoulos dkk., 2015), vehicle routing problem (Bing dkk., 2014) dan time windows (Buhrkaldkk., 2012).

Kecamatan Jati teretak di Kabupaten Kudus, Jawa Tengah. Wilayah Kecamatan Jati didominasi oleh pemukiman, industri dan persawahan. Keadaan topografinya cenderung datar. Jumlah penduduknya sebesar 109.238 jiwa pada tahun 2017 dengan kepadatan penduduk4.154 jiwa $/ \mathrm{km}^{2}$ (BPS Kudus, 2018). Kondisi lingkungan di kecamatan ini relatif cukup baik, dimana sampahnya telah dikelola sehingga menyebabkan lingkungannya bersih. Pengangkutan sampah di Kecamatan Jati sebagian besar dilakukan oleh Pemerintah
Daerah Kabupaten Kudus. Menurut Damanhuri dan Padmi (2003) biaya pengangkutan sampah dapat mencapai $60 \%$ dari total biaya pengelolaan sampah, atau berkisar antara $50-70 \%$ dari total biaya pengelolaan sampah (Tchobanogluous, 1993).

Melihat besarnya total biaya pengelolaan sampah dari sektor transportasi, maka perlu dilakukan optimisasi rute transportasi agar biaya pengelolaan sampah dapat ditekan seminimal mungkin. Selain itu, sektor transportasi sampah juga mempengaruhi jumlah sampah yang dapat terlayani. Sampai sejauh ini, belum ada penelitian yang mengevaluasi kegiatan transportasi sampah di Kecamatan Jati. Penelitian ini bertujuan untukmengetahui kegiatan operasional pengangkutan sampah Kecamatan Jati ditinjau dari kelima aspek pengelolaan sampah.Lebih lanjut lagi, penelitian ini berfokus pada evaluasi dan optimasi sistem manajemen pengangkutan sampah eksisting. Evaluasi dilakukan dengan membandingkan sistem manajemen pengangkutan sebelum dan setelah optimasi yang direncanakan. Harapannya, penelitian ini dapat menjadi sumber referensi bagi peneliti lainnya dalam melakukan optimasi pengelolaan sampah khususnya pada sektor transportasi sampah.

\section{Metodologi Penelitian}

Metode pelaksanaan evaluasi sistem manajemen pengangkutan sampah Kecamatan Jati adalah sebagai berikut:

\section{Pengambilan Data dan Lokasi Sampling}

Penelitian ini dilaksanakan di Kecamatan Jati, Kabupaten Kudus dengan berfokus pada kegiatan pengangkutan dari Dinas Perumahan, Kawasan Permukiman dan Lingkungan Hidup, Kabupaten Kudus. Data diperoleh dari pengukuran, wawancara dan obesrvasi langsung di lapangan. Pengukuran dilakukan dengan mengambil sampel timbulan dan komposisi sampah di Kecamatan Jati menurut SNI 19-2454-2002. Pengambilan sampel routing kendaraan pengangkut sampah berupa dump truck dan arm roll truckdilakukan menggunakan aplikasi My Track. Jalur dari rute setiap kendaraan didigitasi menggunakan salah satu software sistem informasi geografis (SIG), Google Earth, untuk mengetahui jarak tempuhnya. SIG dapat digunakan sebagai alat evaluasi dan optimisasi rute pengangkutan sampah 
disebuah kota (Lella dkk., 2017; Kinobe dkk., 2015).

\section{Analisis dan Pengolahan Data}

Analisis data dilakukan dengan menggunakan acuan dari Peraturan Menteri Pekerjaan Umum (Permen PU) Nomor 3 tahun 2013 tentang Penyelenggaraan Prasarana dan Sarana Persampahan dalam Penanganan Sampah Rumah Tangga dan Sampah Sejenis Sampah Rumah Tangga. Selanjutnya, evaluasi dan optimasi rute dan pola pengangkutan dilakukan dengan membandingkansistemmanajemen pengangkutan sampah yang ada dengan perencanaan sistem manajemen pengangkutan sampah yang optimal.

\section{Hasil dan Pembahasan}

Penyelenggaraan Sistem Pengangkutan Sampah Kecamatan Jati
Penyelenggaraan sistem pengangkutan sampah Kecamatan Jati ditinjau dari lima asepek pengelolaan sampah, yaitu aspek teknis, institusi, pembiayaan, peraturan, dan peran serta masyarakat dan swasta.

\section{Aspek Teknis}

Tingkat pelayanan pengangkutan sampah oleh Pemerintah Daerah Kabupaten Kudus telah menjangkau sebagian besar wilayah Kecamatan Jati. Desa Pasuruha Kidul, Pasuruhan Lor, Jati Wetan, Jati Kulon, Getas Pejaten, Ploso, Getas Pejaten, Tumpang Krasak yang terlayani $100 \%$. Desa Tanjung Karang terlayani 6,25\%; Desa Loram Kulon terlayani 9,35\%; dan Desa Loram Wetan terlayani 5,66\%. Sebagian kecil Kecamatan Jati yaitu Desa Jepang Pakis, Ngembal Kulon, dan Megawon dikelola oleh masyarakat setempat. Gambar 1 menunjukkan peta persentase pelayanan pengangkutan sampah di Kecamatan Jati.

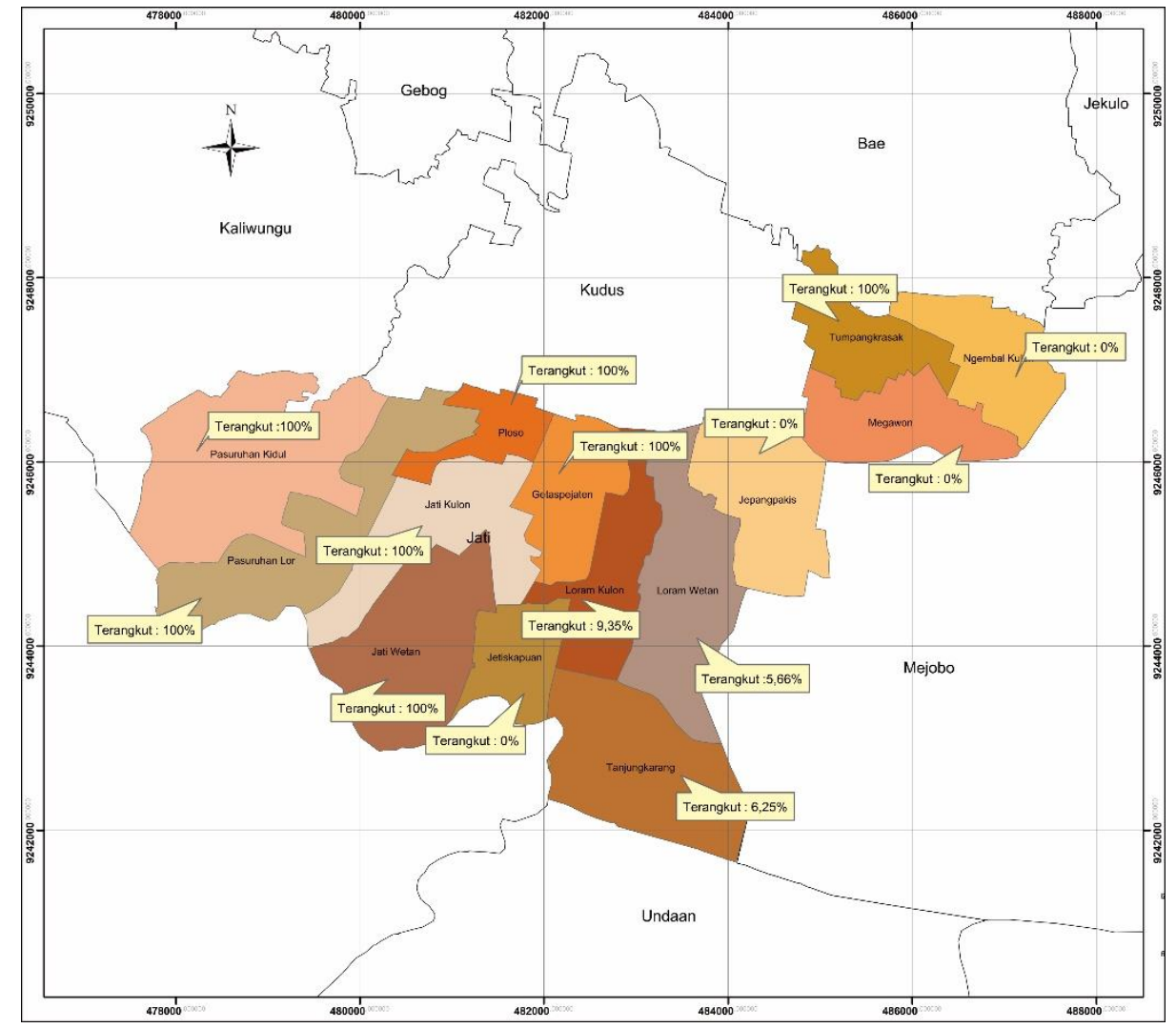

Gambar 1 Peta Pelayanan Kegiatan Pengangkutan Kecamatan Jati

Berdasarkan sampling yang telah dilakukan, timbulan sampah per kapita untuk sampah domestik sebanyak $0,57 \mathrm{~kg} /$ orang/hari dengan volume $0,0048 \mathrm{~m}^{3} /$ orang/hari. Komposisi sampah terbanyak berupa sampah organik yaitu $55,20 \%$. Komposisi sampah lainnya meliputi sampah kertas 7,98\%; sampah kayu $0,22 \%$; sampah kain $5,19 \%$; sampah plastik17,49\%; sampah logam 0,4\%; sampah kaca0,74\%; dan sampah lainnya $4,22 \%$.

Sarana pengangkutan berupa 10 dump truck dan 5 arm roll truck dengan sistem pengangkutan secara langsung dan tak langsung. Waktu kerja yang kurang dapat digunakan secara optimal dalam pelayanan 
pengangkutan sampah. Sarana pengangkut sampah berupa arm roll memiliki kondisi baik, namun beberapa sarana berupa dump truck, 2 diantaranya memiliki kondisi tidak layak dan 1 rusak berat.

Pengangkutan sampah di Kecamatan Jati dilakukan secara langung dan tak langsung. Secara langsung, pengambilan sampah dilakukan pada sumber penghasil sampah. Secara tak langsung, dilakukan pemindahan sampah dari sumber sampah ke transfer depo, baik tipe I, II, maupun III. Sampah yang terangkut berupa sampah tercampur. Terdapat pola pengangkutan gabungan anatara pengangkutan langsung dan tak langsung. Pengangkutan tak langsung menggunakan Hauled Container System (HCS) dan Stationary Container System (SCS) manual. Sarana pengangkutan berupa dump truck dan arm roll truck. Waktu operasional pengangkutan untuk pelayanan transfer depo dengan dump truck adalah 45 jam per minggu. Sedangkan pelayanan dump truckmenggunakan sistem pengangkutan langusung, pelayanan pasar dan arm roll truck memiliki waktu operasional 53 jam per minggu. Secara umum, pola, rute dan sarana telah ditentukan oleh Dinas PKPLH, namun secara teknis dilapangan diatur sendiri oleh pengemudi kendaraan pengangkut sampah.

\section{Aspek Institutisi}

Bidang pengelolaan persampahan dan ruang terbuka hijau seksi pengelolaan persampahan dan limbah B3 melakukan pengelolaan sampah termasuk manajemen sistem pengangkutan. Secara lebih khusus, terdapat koordinator pada pengangkutan sampah yang bertugas merencanakan rute pengangkutan, dan sarana pengangkutan serta mengawasi jalannya pelayanan pengangkutan sampah.

\section{$\underline{\text { Pembiayaan }}$}

Dalam kegiatan operasinya, sistem pengangkutan memerlukan anggaran yang meliputi bahan bakar, anggaran perawatan dan pemeliharaan, serta upah tenaga kerja. Retribusi dikenakanterhadappelayanan persampahan / kebersihan yang besarnya bervariasi untuk setiap pengelompokan. Secara lebih rinci, tarif retribusi tercantum pada Peraturan Derah Kabupaten Kudus Nomor 12 tahun 2010 tentang Retribusi Pelayanan Persampahan/Kebersihan.

\section{Peraturan}

Pengelolaan sampah termasuk pengangkutannya oleh Dinas PKPLH berpedoman pada Peraturan Daerah Kabupaten Kudus Nomor 4 tahun 2017 tentang Pengelolaan Sampah. Selain itu retribusi pelayanan persampahan/kebersihan dilaksanakan menurut Peraturan Daerah Kabupaten Kudus Nomor 12 tahun 2010 tentang Retribusi Pelayanan

Persampahan/Kebersihan.

\section{Peran Serta Masyarakat dan Swasta}

Pengangkutan sampah di Kecamatan Jati tidak hanya dilakukan oleh Dinas PKPLH. Masyarakat dan swasta turut berpartisipasi dalam pengangkutan sampah menuju TPA. Masyarakat dalam pelaksanaannya dilakukan dengan berkoordinasi dengan pemerintah desa setempat atau dengan kelompok individu yang melakukan pengangkutan secara mandiri keTPA. Dalam hal ini, sarana pengangkut sampah yang digunakan berupa becak motor. Sedangkan pihak swasta seperti beberapa industri, melakukan pengangkutan langsung menuju TPA dengan menggunakan sarana pengangkutan berupa dump truck.

Optimasi Pengangkutan Sampah Kecamatan Jati, Kabupaten Kudus

Pengangkutan sampah didasarkan pada Permen PU Nomor 3 tahun 2013 yang dibagi menjadi pengangkutan langsung dan tak langsung.

\section{Pengangkutan Langsung}

Perhitungan dan perencanaan pengangkutan langsung berdasarkan pada akumulasi timbulan sampah terangkut per minggunya dari setiap titik layanan menurut data Daya Tampung TPS di Wilayah Kabupaten Kudus tahun 2017. Hasil akumulasi timbulanyang harus terangkut per minggunya sebesar 443,53 $\mathrm{m}^{3}$. Kapasitas setiap dump truck sebesar $8 \mathrm{~m}^{3}$ dengan faktor pemadatan 1,2 menurut SNI 3242-2008 tentang Pengelolaan Sampah di Permukiman. Dengan demikian, diperlukan kontainer atau bak sebanyak 56 unit. Diasumsikan setiap kendaraan dapat melakukan2 rit per hari, sehingga sarana pengangkut sampah yang dibutuhkan sebanyak 4 unit dump truck. 
Tabel 1 Rute dan Timbulan Sampah Terangkut Pengangkutan Langsung Sebelum dan Sesudah Optimasi

\begin{tabular}{|c|c|c|c|c|}
\hline \multirow[t]{2}{*}{ Nopol } & \multirow{2}{*}{$\begin{array}{c}\text { Lokasi Pengambilan } \\
\text { Sampah Sebelum } \\
\text { Optimasi }\end{array}$} & \multirow{2}{*}{$\begin{array}{l}\text { Lokasi Pengambilan Sampah Sesudah } \\
\text { Optimasi }\end{array}$} & \multicolumn{2}{|c|}{$\begin{array}{c}\text { Timbulan Sampah } \\
\text { Terangkut/Minggu } \\
\left(\mathrm{m}^{3}\right)\end{array}$} \\
\hline & & & $\begin{array}{l}\text { Sebelum } \\
\text { Optimasi }\end{array}$ & $\begin{array}{l}\text { Sesudah } \\
\text { Optimasi }\end{array}$ \\
\hline $\begin{array}{l}\text { K } 9548 \\
A B\end{array}$ & $\begin{array}{l}\text { POM Bensin Matahari, } \\
\text { Terminal Getas, R.M } \\
\text { Pak Denuh, Hotel } \\
\text { Griptha, Hotel King, } \\
\text { GOR Djarum Jati, POM } \\
\text { Bensin Tanjung, Djarum } \\
\text { Tanjung Karang, PT. } \\
\text { Jaya Transport, R.S } \\
\text { Mardi Rahayu, Pasar } \\
\text { Barongan }\end{array}$ & $\begin{array}{l}\text { POM Bensin Tanjung, Djarum Tanjung } \\
\text { Karang, Djarum Gudang Gulang, SPBU } \\
\text { Payaman, PT. Mercu Pantura Industri, SMP } \\
1 \text { Mejobo, SKT Megawon 123, SMA } 2 \\
\text { Kudus, Pasar Besito, Perum Conge, Perum } \\
\text { Sumber, HET Kesambu/UD Tiga Putra, } \\
\text { Djarum Bulungcangkring, PT. Victory Supra } \\
\text { Sigaret, PT. Jamrud Katulistiwa, PT. } \\
\text { Tansentra Tobacco, Djarum Terban, PT. } \\
\text { Sinar Indah Kertas, PT. Chandra Asri Mulia }\end{array}$ & 118,92 & 111,21 \\
\hline $\begin{array}{l}\text { K } 1629 \\
\text { YB }\end{array}$ & $\begin{array}{l}\text { Hypermart, Rusunawa, } \\
\text { Djarum Mijen, Dajrum } \\
\text { Kedungdowo, Stevani } \\
\text { Ultra Kaliwungu, Djarum } \\
\text { Sidorekso, SKT } \\
\text { Megawon 123, PT. } \\
\text { Mercu Pantura Industry, } \\
\text { Perum Sumber, HET } \\
\text { Kesambi, SKT } \\
\text { Bulungcangkring, TPA }\end{array}$ & $\begin{array}{l}\text { R.M Ulam Sari, Mulyatex, Terminal Getas, } \\
\text { POM Bensin Matahari, Matahari, Terminal } \\
\text { Jetak, Djarum Sidorekso, Stevani Ultra } \\
\text { Kaliwungu, Djarum Karangampel, Transfer } \\
\text { Depo Kudus Permai, Taman Boejana, } \\
\text { Rumah Roti Kartini, Pasar Barongan, } \\
\text { Djarum Super, PT. Savoria, GOR Djarum } \\
\text { Klaiputu, Djarum Aval, PT. Nojorono, Jl. } \\
\text { Tanjung 1-2, HotelAir Mancur,TPA }\end{array}$ & 42,12 & 111 \\
\hline $\begin{array}{l}\text { K } 9530 \\
A B\end{array}$ & $\begin{array}{l}\text { PLN Area Kudus, Ds. } \\
\text { Pasuruhan Lor, } \\
\text { Swalayan Ada, Djarum } \\
\text { Jetak, Polsek Kaliwungu, } \\
\text { Djarum Brak Garung, } \\
\text { Djarum Karangampel, } \\
\text { Djarum Brak SKM } \\
\text { Gribig, Pos Pemadam } \\
\text { Kebakaran, RND Djarum } \\
\text { Kudus, SOS, IPAL, PT. } \\
\text { Leni Jambean, Jl. } \\
\text { Tanjung }\end{array}$ & & 25,60 & \\
\hline $\begin{array}{l}\text { K } 9545 \\
\text { AB }\end{array}$ & $\begin{array}{l}\text { R.M Bale Raos, R.M } \\
\text { Ulam Sari, Djarum } \\
\text { Kaliputu, Djarum } \\
\text { Burikan, PT. Savoria, } \\
\text { GOR Djarum Kaliputu, } \\
\text { Djarum Aval, Perum } \\
\text { Muria Permai, PT. Multi } \\
\text { Sarana, PT. Djarum IUI, } \\
\text { Djarum Karangebener, } \\
\text { Perum Conge, SMK 1 } \\
\text { Bae, SMP 1 Mejobo, } \\
\text { SPBU Payman, PT. } \\
\text { Jamrud, PT. Victory, PT. } \\
\text { Trans Centra, Djarum } \\
\text { Terban, PT. Sinar Indah } \\
\text { Kertas, PT. CAMA, } \\
\text { Matahari, Noyorono, JI. } \\
\text { Sunan Muria, RM } \\
\text { Kartini, Jalan Gatot } \\
\text { Subroto, Sultan Chicken, } \\
\text { Jl. Simpang } 7\end{array}$ & $\begin{array}{l}\text { Hypermart, Hotel Griptha, Hotel King, PT. } \\
\text { Bhakti Usaha Nusantara, Djarum Workshop, } \\
\text { Djarum Cerutu, PT. Utama Multinaga } \\
\text { Indonesia, Djarum Kedungdowo, Djarum } \\
\text { Mijen, Perum Muria Asri, R.S Yakis, Djarum } \\
\text { Brak SKM Gribig, Djarum SKT Sudimoro, } \\
\text { IPAL, SOS, RND Djarum Kudus, Rusunawa, } \\
\text { Pabrik Noyorono1-2, PT. Multisarana, PT. } \\
\text { Djarum Intertobacco Utama Industry, PT. } \\
\text { Djarum Karangbener, TPA }\end{array}$ & 49,66 & 111,20 \\
\hline
\end{tabular}


Selanjutnya, dilakukan pembagian beban pengangkutan secara merata untuk setiap kendaraan pengangkut. Dalam hal ini, diasumsikan penyapuan jalan dilakukan oleh dump truck khusus untuk pengangkutan sampah hasil penyapuan jalan, sehingga pengangkutan sampah titik layanan dan penyapuan jalan dianggap terpisah. Perbandingan beban pengangkutan pengangkutan langsung sebelum dan setelah optimasi terdapat pada Tabel 1.

\section{Pengangkutan Tidak Langsung (HCS)}

Perhitungan dan perencanaan pengangkutan langsung didasarkan pada jumlah timbulan sampah yang harus terangkut per minggunya pada setiap titik layanan, sehingga didapatkan rit tiap minggunya. Dengan memperhatikan waktu efektif kerja yang didapatkan dari waktu tempuh, waktu bongkar muat di TPS dan TPA serta waktu off route (Nowakowski dkk., 2018).

Berdasarkan hasil perhitungan, didapatkan akumulasi waktu efektif dari semua titik layanan per minggunya sebesar 249,62 jam/minggu. Waktu operasional yang diberikan untuk pengangkutan sistem ini adalah $53 \mathrm{jam} / \mathrm{minggu}$. Dengan demikian, jumlah arm roll truck yang dibutuhkan sebanyak 5 unit dan telah sesuai dengan kondisi saat ini.

Pengangkutan Tidak Langsung (SCS)
Demikian halnya dengan pengangkutan tak langsung SCS, perhitungan dan perencanaanya didasarkan pada timbulan sampah dengan memperhatiakan waktu efektif kerja. Selain itu, untuk mengurangi waktu tempuh, dilakukan pemilihan jalur yang lebih singkat. Sarana pengangkut sampah dengan kondisi yang tidak baik digantikan dengan kendaraan yang memiliki kondisi baik untuk menunjang kelancaran operasional pengangkutan sampah. Dalam hal ini dump truck dengan nomor polisi H 9560 BG digantikan dengan $\mathrm{K} 9530 \mathrm{AB}$ dan dump truck dengan nomor polisi K 9556 B digantikan dengan K 9533 AB. Waktu efektif per kendaraan pada pengangkutan SCS sebelum dan setelah optimasi disajikan pada Tabel 2.

\section{$\underline{\text { Rute Pengangkutan }}$}

Menurut Permen PU Nomor 3 tahun 2013, Pembagian rute pengangkutan harus seimbang (<15\%).Dapat dilihat bahwa sebelum dilakukan optimasi, pembagian lokasi pengambilan sampah cenderung tidak merata, sehingga berdampak pada waktu efektif kerja untuk sistem pengangkutan langsung. Sedangkan untuk sistem pengangkutan tak langsung, pelayanan pengangkutan sampah lebih maksimal dengan waktu efektif kerja yang lebih merata pada setiap pengemudi kendaraan pengangkut sampah serta dapat memaksimalkan kapasitas angkut sarana pengangkut sampah setelah dilakukan optimasi.

Tabel 2 Waktu Efektif Per Kendaraan Pengangkutan SCS Sebelum dan Setelah Optimasi

\begin{tabular}{|c|c|c|c|c|c|}
\hline Nopol & $\begin{array}{c}\text { Lokasi } \\
\text { pengumpulan }\end{array}$ & Rit/mgg & $\begin{array}{c}\text { Waktu } \\
\text { efektif } \\
\text { Sebelum } \\
\text { Optimasi / } \\
\text { minggu } \\
\text { (jam) }\end{array}$ & Rit/mgg & $\begin{array}{l}\text { Waktu Efektif } \\
\text { Setelah } \\
\text { Optimasi / } \\
\text { Minggu (jam) }\end{array}$ \\
\hline \multirow[t]{2}{*}{ K 9540 AB } & Getas Pejaten & 12 & 35,64 & 12 & 39,97 \\
\hline & Pasar Bitingan & & & 2 & \\
\hline \multirow[t]{2}{*}{ K 9530 AB } & Getas Pejaten & 7 & 24,99 & 12 & 39,97 \\
\hline & Pasar Bitingan & & & 2 & \\
\hline \multirow[t]{2}{*}{ K 9533 AB } & Tumpang Krasak & 7 & 24,08 & 10 & 41,10 \\
\hline & Pasar Bitingan & & & 5 & \\
\hline K 9536 AB & Pasar Bitingan & 21 & 56,63 & 19 & 51,88 \\
\hline
\end{tabular}


golongannya, rata- rata berkisar $\mathrm{Rp}$ 2.500.000,00 per tenaga kerja.Sebelum

Pembiayaan pengangkutan sampah terdiri dari anggaran bahan bakar, anggaran pemeliharaan dan perawatan, dan upah tenaga kerja. Anggaran bahan bakar tergantung dari jauhnya jarak tempuh dengan harga bahan bakar solar saat ini adalah Rp $5.150,00$. Anggaran pemeliharaan dan perawatan kendaraan pada tahun 2018 adalah sebesar Rp 3.800.000,00 untuk servis ringan per unit dump truck atau arm roll truck. Servis sedang per unit kendaraan sebesar Rp 4.200.000,00. Servis berat per unitkendaraan sebesar Rp 4.700.000,00 untuk dump truk; dan Rp 4.500.000,00 untuk arm roll truck. Dosmir biasa sebesar Rp 600.000,00 per unit kendaraan dan dosmir lengkap sebesar Rp1.500.000,00 per unit kendaraan. Upah tenaga kerja bervariasi tergantung optimasi, terdapat 10 dump truck yang beroperasi dengan kondisi kendaraan 2 tidak layak, 1 rusak berat, dan 7 baik. Setelah dilakukan optimasi, dump truck yang dioperasikan berjumlah 8 buah dengan kondisi kendaraan 1 rusak berat dan 7 baik. Kendaraan berupa arm roll truck yang beroperasi sebelum optimasi dan sesudah optimasi tetap berjumlah 5 buah dengan kondisi semua kendaraan baik. Tenaga kerja pengemudi kendaraan pengangkut diasumsikan 1 orang per kendaraan, sehingga didapatkan sebelum optimasi berjumlah 15 orang dan setelah optimasi berjumlah 13 orang. Dengan demikian, didapatkan hasil perbandingan pembiayaan sistem pengangkutan sampah Kecamatan Jati sebelum dan setelah optimasi pada Tabel 3 .

Tabel 3 Perbedaan Biaya Operasional Sistem Pengangkutan Kecamatan Jati

\begin{tabular}{llr}
\hline No. & Kebutuhan & Saving Anggaran Setelah Optimasi (Rp/bulan) \\
\hline 1 & Bahan bakar & Rp. $10.062 .047,-$ \\
2 & Pemeliharaan dan perawatan & Rp. 13.600.000,- \\
3 & Upah tenaga pengangkut & Rp. $5.000 .000,-$ \\
\hline Total & & Rp. 28.662.047,-- \\
\hline
\end{tabular}

\section{Kesimpulan}

Sistem manajemen pengangkutan sampah eksisting di Kecamatan Jati sudah cukup baik. Namun, pada teknik operasional dan pembiayaannya terdapat beberapa hal yang dapat dievaluasi dan dioptimasi. Pemilihan pola pengangkutan sampah sistem HCS pengosongan kontainer dinilai kurang efisien, sehingga bahan bakar yang dibutuhkan lebih banyak. Pembagian rute pengangkutan sampah kurang merata, dampaknya waktu efektif kerja setiap pengemudi kendaraan dan timbulan sampah yang terangkut antar pengemudi kendaraan pengangkut sampah tidak seimbang. Selain itu, 2 unit dump truck yang diketahui dalam kondisi tidak layak dan rusak berat tetapi masih beroperasi. Penerapan optimasi sistem pengangkutan Kecamatan Jati diketahui dapat mengurangi anggaran pengangkutan sehingga kegiatan optimasi sangat menguntungkan apabila dapat dilaksanakan. Dengan demikian, pemerintah daerah setempat dapat melakukan pelayanan pengangkutan sampah secara maksimal, menggunakan waktu kerja secara efektif, mengefisienkan sarana pengangkutan sampah serta dapat mengurangi anggaran manajemen sampah secara keseluruhan.

Ucapan Terima Kasih: Terima kasih kepada Dinas Perumahan, Kawasan Permukiman dan Lingkungan Hidup (PKPLH), Kabupaten
Kudus yang telah memberikan dukungan berupa data-data transportasi sampah Kecamatan Jati kepada penulis.

\section{Daftar Pustaka}

Anagnostopoulos, T., Kolomvatsos K., Anagnostopoulos C., Zaslavsky, A., Hadjiefthymiades S. (2015). Assessing dynamic models for high priority waste collectionin smart cities. The Journal of Systems and Software, 110: 178-192.

Arnatha, I.M. (2012). Studi Optimasi Teknik Operasional Pengumpulan dan Pengangkutan Sampah dengan Model Simulasi. Jurnal IImiah Teknik Sipil, 16(1): 90-99.

Badan Pusat Statistik (BPS) Kudus. (2018). Kecamatan Jati dalam Angka 2018. Badan Pusat Statistik Kabupaten Kudus: Kudus.

Bing, X., de Keizer, M., Bloemhof-Ruwaard J.M., van der Vorst, J.G.A.J. (2014). Vehicle routing for the eco-efficient collection of household plasticwaste. Waste Management, 34: 719-729.

Buhrkal, K., Larsen, A., Ropke, A. (2012). The waste collection vehicle routing problem with timewindows in a city logistics context. Procedia - Social and Behavioral Sciences, 39: 241254. 
Damanhuri, E., \& Padmi, T. (2003). Pengelolaan Sampah. Bandung : Fakultas Teknik Sipil dan Lingkungan Institut Teknologi Bandung.

Huang, S-H., Lin, P-C. Vehicle routingscheduling for municipal waste collection systemunder the "Keep Trash off the Ground" policy. Omega, 55: 24-37.

Ismail, A.H., Usman, Y.V., Hidayah, N.Y., Chairani, L. (2012). Metropolitan Cities s Waste Transportation Model. Procedia - Social and Behavioral Sciences, 65: 10461053.Kementerian Pekerjaan Umum. (2013). Peraturan Menteri Pekerjaan Umum tentang Penyelenggaraan Prasarana dan Sarana Persampahan dalam Penanganan Sampah Rumah Tangga dan Sampah Sejenis Sampah Rumah Tangga.

Kementrian Lingkungan Hidup. (2008). Undang- Undang Republik Indonesia Nomor 18 Tahun 2008 tentang Pengelolaan Sampah. Jakarta.

Kinobe, J.R., Bosona, T., Gebresenbet, G., Niwagaba, C.B., Vinneras, B. 2015. Optimization of waste collection and disposal in Kampala city. Habitat International, 49: 126-137.

Lella, J., Mandla, V.R., Zhu, X. (2017). Solid waste collection/transport optimization and vegetation land coverestimation using Geographic Information System (GIS): A case study of aproposed smart-city. Sustainable Cities and Society, 35: 336-349.

Nowakowski, P., Szwarc, K., Boryczka, U. Vehicle route planning in e-waste mobile collection on demandsupported by artificial intelligence algorithms. Transportation Research Part D, 63: 1-22.

Pemerintah Daerah Kabupaten Kudus. (2010). Peraturan Daerah Kabupaten Kudus Nomor 12 Tahun 2010 tentang Retribusi Pelayanan Persampahan Kebersihan.

Ridha, M.R., Abdi, C., dan Mahyudin, R.P. (2016). Studi Optimasi Rute Pengangkutan Sampah Kota Marabahan dengan Sistem Informasi Geografis. Jukung Jurnal Teknik Lingkungan, 2(2): 38-51.

Tchobanoglous, G., Hilary, T., \& Samuel, A. V. (1993). Integrated Solid Waste Managemment : Engineering Principles and Management Issues. [International Edition]. New York: McGraw-Hill

Pemerintah Republik Indonesia. (2008). Undang-Undang Republik Indonesia Nomor 18 tahun 2008 tentang Pengelolaan Sampah.Jakarta.

SNI 19-2454-2002. (2002) Tata Cara Teknik Operasional Pengelolaan Sampah Perkotaan. Departemen Pekerjaan Umum. Bandung : Yayasan LPMB.

SNI 3242:2008. (2008). Pengelolaan Sampah di Permukiman. Departemen Pekerjaan Umum. Bandung : Yayasan LPMB.

Zalukhu, S.A., dan Mirwan, M. (2018). Analisis Model Dinamik dalam Pengangkutan Sampah di Kota Bangkalan. Jurnal Envirotek, 10(1): 28-36. 